\title{
Tackling resistance: emerging antimalarials and new parasite targets in the era of elimination [version 1; peer review: 2
} approved]

\author{
Emily S. Mathews (iD), Audrey R. Odom John 1,2 \\ ${ }^{1}$ Department of Pediatrics, Washington University School of Medicine, St. Louis, Missouri, USA \\ ${ }^{2}$ Department of Molecular Microbiology, Washington University School of Medicine, St. Louis, Missouri, USA
}

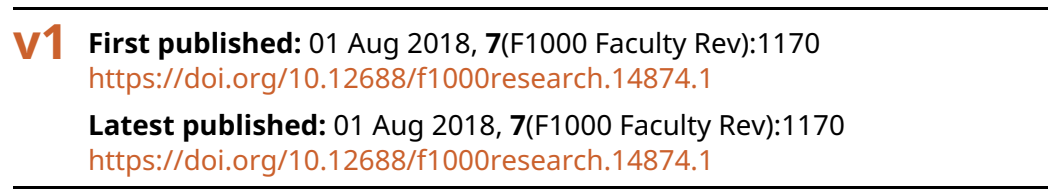

\section{Abstract}

Malaria remains a significant contributor to global human mortality, and roughly half the world's population is at risk for infection with Plasmodium spp. parasites. Aggressive control measures have reduced the global prevalence of malaria significantly over the past decade. However, resistance to available antimalarials continues to spread, including resistance to the widely used artemisinin-based combination therapies. Novel antimalarial compounds and therapeutic targets are greatly needed. This review will briefly discuss several promising current antimalarial development projects, including artefenomel, ferroquine, cipargamin, SJ733, KAF156, MMV048, and tafenoquine. In addition, we describe recent large-scale genetic and resistance screens that have been instrumental in target discovery. Finally, we highlight new antimalarial targets, which include essential transporters and proteases. These emerging antimalarial compounds and therapeutic targets have the potential to overcome multi-drug resistance in ongoing efforts toward malaria elimination.

Keywords

Plasmodium, antimalarial, drug targets, drug discovery, resistance

\author{
Open Peer Review \\ Approval Status \\ 1 \\ 2 \\ version 1 \\ 01 Aug 2018 \\ Faculty Reviews are review articles written by the \\ prestigious Members of Faculty Opinions. The \\ articles are commissioned and peer reviewed \\ before publication to ensure that the final, \\ published version is comprehensive and \\ accessible. The reviewers who approved the final \\ version are listed with their names and \\ affiliations. \\ 1. Kirsten Hanson, University of Texas at San \\ Antonio, San Antonio, USA

\section{Emily Derbyshire, Duke University Medical} \\ Center, Durham, USA
}

Any comments on the article can be found at the end of the article. 
Corresponding author: Audrey R. Odom John (aodom@wustl.edu)

Author roles: Mathews ES: Visualization, Writing - Original Draft Preparation, Writing - Review \& Editing; Odom John AR: Writing Original Draft Preparation, Writing - Review \& Editing

Competing interests: No competing interests were disclosed.

Grant information: This work was supported by the National Institutes of Health (R01AI103280 and R21AI123808-01 to Audrey Odom John and T32AI007172-37 to Emily Mathews), the Children's Discovery Institute of Washington University and St. Louis Children's Hospital (Audrey Odom John), and the Burroughs Wellcome Fund (to Audrey Odom John).

The funders had no role in study design, data collection and analysis, decision to publish, or preparation of the manuscript.

Copyright: ( 2018 Mathews ES and Odom John AR. This is an open access article distributed under the terms of the Creative Commons Attribution License, which permits unrestricted use, distribution, and reproduction in any medium, provided the original work is properly cited.

How to cite this article: Mathews ES and Odom John AR. Tackling resistance: emerging antimalarials and new parasite targets in the era of elimination [version 1; peer review: 2 approved] F1000Research 2018, 7(F1000 Faculty Rev):1170

https://doi.org/10.12688/f1000research.14874.1

First published: 01 Aug 2018, 7(F1000 Faculty Rev):1170 https://doi.org/10.12688/f1000research.14874.1 


\section{Introduction}

Malaria has posed a risk to human life since the origin of our species. Despite this long history, it was not until 1880 that French army surgeon Charles Louis Alphonse Laveran discovered intraerythrocytic parasites in the blood of a patient with malaria ${ }^{1}$. Immediately following Laveran's discovery, crucial aspects of this infection, including species classification and the details of the human-mosquito transmission cycle, were revealed ${ }^{2-6}$. These early studies shaped our understanding of the protozoan parasites of genus Plasmodium that cause malaria. In the complex life-cycle of Plasmodium spp., human infection begins with the bloodmeal of a female Anopheles mosquito. Parasites migrate to the liver, where they undergo a large, asymptomatic expansion, emerging to invade red blood cells and initiate asexual replication. A small fraction of these blood-stage parasites terminally differentiate into gametocytes that are taken up by the mosquito to complete sexual replication and begin the infection cycle anew. Five different species of Plasmodium cause the majority of human malaria: P. falciparum, $P$. knowlesi, $P$. malariae, $P$. ovale, and $P$. vivax. Malaria still accounts for an estimated 445,000 deaths and 216 million cases annually, and the majority of deaths result from infection with P. falciparum ${ }^{7}$.

Malaria deaths have declined in large part because of the development of effective antimalarial medicines. Beginning in the late 1940s, chloroquine was the standard treatment for uncomplicated malaria ${ }^{8}$. However, by the late 1950s and early 1960s, chloroquine-resistant $P$. falciparum was observed throughout Southeast Asia, Oceania, and South America. Resistance to chloroquine has since spread to nearly all areas of the world ${ }^{9}$. Subsequent resistance has developed to antimalarials such as sulfadoxine/pyrimethamine, mefloquine, halofantrine, and quinine ${ }^{10}$. Most recently, resistance to artemisinin-based combination therapies emerged in 2008 in parts of Southeast Asia and continues to spread ${ }^{11-19}$. Clinical artemisinin resistance manifests as a delayed clearance phenotype; that is, infection eventually resolves with treatment with artemisinin-based combination therapy, but the time required for parasite clearance substantially increases ${ }^{14,20,21}$. This delayed clearance could contribute to the even more troubling rise in multi-drug resistance, as parasites have gained both reduced artemisinin sensitivity ${ }^{22}$ and resistance against partner drugs, such as piperaquine ${ }^{12,19}$. As multi-drug resistance spreads, there is an urgent need for new antimalarial agents to control malaria infections. Optimally, new antimalarials will overcome multi-drug resistance, will be highly safe for use in vulnerable populations (such as infants and pregnant women), and will target more than one life-cycle stage in order to break the cycle of transmission. In this brief review, we highlight promising novel antimalarials currently in development and introduce emerging drug targets that may be key to ongoing efforts to eliminate malaria worldwide.

\section{Promising new antimalarials in development}

Global efforts to end malaria have led to the development of promising compounds. At the forefront of antimalarial development is the Medicines for Malaria Venture (MMV), which was established in 1999 as a not-for-profit, public-private partnership. The current MMV portfolio contains many promising compounds at various stages of development (research, translational, product development, and access; https://www.mmv.org/ research-development/mmv-supported-projects). To illustrate the diversity of the current portfolio, a selection of the emerging antimalarials currently in development is discussed below (Table 1) $)^{23-29}$.

Table 1. Selected promising antimalarial compounds.

\begin{tabular}{|c|c|c|c|c|}
\hline $\begin{array}{l}\text { Antimalarial } \\
\text { compound }\end{array}$ & $\begin{array}{l}\text { Alternative } \\
\text { names }\end{array}$ & $\begin{array}{l}\text { Protein target/predicted } \\
\text { target }\end{array}$ & Target candidate profiles ${ }^{a}$ & Current status in MMV pipeline ${ }^{b}$ \\
\hline Artefenomel & OZ439 & Unknown & $\begin{array}{l}\text { Asexual parasite clearance; } \\
\text { transmission blocking }\end{array}$ & $\begin{array}{l}\text { Combined artefenomel-ferroquine is } \\
\text { in the patient-exploratory stage }\end{array}$ \\
\hline Cipargamin & $\begin{array}{l}\text { KAE609, } \\
\text { NITD609 }\end{array}$ & $\begin{array}{l}\text { PfATP4, based on resistance } \\
\text { screen mutations }{ }^{23}\end{array}$ & $\begin{array}{l}\text { Asexual parasite clearance; } \\
\text { transmission blocking }\end{array}$ & Patient-exploratory stage \\
\hline DSM265 & Not applicable & Plasmodium $\mathrm{DHODH}{ }^{24}$ & $\begin{array}{l}\text { Asexual parasite clearance; } \\
\text { targeting liver schizonts }\end{array}$ & Patient-exploratory stage \\
\hline Ferroquine & SSR97193 & Unknown & $\begin{array}{l}\text { Asexual parasite clearance; } \\
\text { transmission blocking }\end{array}$ & $\begin{array}{l}\text { Combined artefenomel-ferroquine is } \\
\text { in the patient-exploratory stage }\end{array}$ \\
\hline KAF156 & GNF156 & $\begin{array}{l}\text { PfCARL }^{25}, \text { PfACT, and } P f \cup G T^{26} \text {, } \\
\text { based on resistance screen } \\
\text { mutations }\end{array}$ & $\begin{array}{l}\text { Asexual parasite clearance; } \\
\text { transmission blocking; } \\
\text { targeting liver schizonts }\end{array}$ & $\begin{array}{l}\text { Combined KAF156-lumefantrine is in } \\
\text { the patient-exploratory stage }\end{array}$ \\
\hline MMV048 & MMV390048 & Plasmodium $\mathrm{PI} 4 \mathrm{~K}^{27}$ & $\begin{array}{l}\text { Asexual parasite clearance; } \\
\text { transmission blocking; } \\
\text { targeting liver schizonts }\end{array}$ & Patient-exploratory stage \\
\hline SJ733 & (+)-SJ000557733 & $\begin{array}{l}\text { PfATP4, based on resistance } \\
\text { screen mutations }^{28,29}\end{array}$ & $\begin{array}{l}\text { Asexual parasite clearance; } \\
\text { transmission blocking }\end{array}$ & Human volunteer stage \\
\hline Tafenoquine & $\begin{array}{l}\text { WR } 238605 \\
\text { Etaquine }\end{array}$ & Unknown & $\begin{array}{l}\text { Targeting Plasmodium } \\
\text { hypnozoites }\end{array}$ & Regulatory review stage \\
\hline
\end{tabular}

$\mathrm{DHODH}$, dihydroorotate dehydrogenase

PI4K, phosphatidylinositol 4-kinase

${ }^{a}$ According to Medicines for Malaria Venture (MMV) Target Candidate Profile classification.

Status as of 31 July 2018. 


\section{Artefenomel and ferroquine}

The current standard of care for malaria is combination therapy based on artemisinin, which is highly valued as a potent, rapidly active antiparasitic compound. Like artemisinin, synthetic ozonides contain an endoperoxide bond. A first-generation ozonide, arterolane (OZ277), has already been licensed for clinical use in India as a combination therapy with piperaquine. However, concern has arisen that there may be a loss of potency against kelch13 mutant parasites, which are artemisinin resistant ${ }^{30-33}$. Other synthetic ozonides, including artefenomel (OZ439), have been developed ${ }^{34}$. Artefenomel displays activity in transmissionblocking assays in vitro ${ }^{35}$, and clinical studies support its use in a single-exposure combination therapy ${ }^{36}$. Unlike artemisinin's peroxide bond, artefenomel's peroxide bond is more stable and has an improved half-life in plasma: 23 hours compared with 0.5 hours $^{34}$. Promisingly, artemisinin-resistant mutants do not appear to be cross-resistant to artefenomel ${ }^{30,31}$, although some mutations in kelch13 may lead to partial cross-resistance ${ }^{30-33}$. Together, these properties support the continued efforts toward development and licensure of artefenomel for clinical use.

Ferroquine is a third-generation 4-aminoquinoline and a derivative of the antimalarial chloroquine. Although chloroquine resistance has spread to nearly all areas of the world, ferroquine efficacy is not impeded by chloroquine resistance mechanisms and resistance selection has not been observed in the laboratory ${ }^{37}$. Ferroquine also retains activity against parasites resistant to chloroquine, mefloquine, quinine, and piperaquine ${ }^{38,39}$. An initial clinical study with ferroquine in combination with artesunate showed a high malaria cure rate, and treatment with ferroquine also displayed post-treatment prophylaxis activity for at least 2 months $^{40}$. Recent phase 2 trials replaced artesunate with the more effective artefenomel ${ }^{40-42}$, and a combination of artefenomel and ferroquine therapy is in the patient-exploratory stage of the MMV portfolio.

\section{DSM265}

Plasmodium spp. depend on de novo pyrimidine synthesis because they lack pyrimidine salvage enzymes. An essential enzyme in the pyrimidine biosynthesis pathway is dihydroorotate dehydrogenase (DHODH). Large high-throughput screens were conducted to identify PfDHODH inhibitors ${ }^{43,44}$. These screens identified several classes of molecules that target DHODH, such as triazolopyrimidines, phenylbenzamides, ureas, and naphthamides ${ }^{44}$. One triazolopyrimidine that has potent activity against asexual and liver-stage parasites is DSM265 ${ }^{45}$. DSM265 selectively inhibits Plasmodium spp. DHODH enzymes over human orthologues ${ }^{24}$. DSM265 is currently in the patientexploratory stage of the MMV pipeline and exhibits promising single-dose efficacy. Interestingly, DSM265 is predicted to remain at therapeutic concentrations in humans for more than a week after a single dose because of its favorable pharmacokinetic properties ${ }^{45}$. DSM265 also has promising prophylactic activity, providing some protection against infection with a single dose up to 7 days before parasite challenge ${ }^{46,47}$. The single-dose efficacy of DSM265 makes it exceptionally promising for both prophylaxis and treatment of disease. Furthermore, the potency of DSM265 supports future development of compounds that target Plasmodium DHODH.
Cipargamin and SJ733

Cipargamin (KAE609), a spiroindolone, also has potent activity against blood-stage malaria parasites ${ }^{23,48}$. A recent phase 2 study used once-daily dosing of cipargamin for 3 days on 21 adults with either uncomplicated $P$. vivax or $P$. falciparum malaria ${ }^{49}$. Parasite clearance rates in this clinical study and in vitro are among the fastest of any antimalarial yet characterized ${ }^{23,49}$. Cipargamin likely targets the P-type $\mathrm{Na}^{+}$ATPase, PfATP4, because resistance mutations have emerged ${ }^{23}$. PfATP4 appears to regulate parasite ion homeostasis, which is essential for survival, through active $\mathrm{Na}^{+}$export ${ }^{50}$. Inhibition of PfATP4, through cipargamin treatment, perturbs ion homeostasis in the parasite and increases host cell membrane rigidity, resulting in blocked blood-stage development and transmission to mosquitoes $28,29,50-52$. Cipargamin is currently in the patient-exploratory stage of the MMV portfolio; however, it is not the only PfATP4 inhibitor currently in development. A diverse range of compounds, including spiroindolones ${ }^{23,51,53}$, pyrazoleamides ${ }^{29}$, aminopyrazoles ${ }^{53}$, dihydroisoquinolones ${ }^{28}$, and other compounds ${ }^{54}$, have been shown to target PfATP4. A dihydroisoquinolone that likely targets PfATP4, SJ733, is in the human volunteer stage of the MMV portfolio. Resistance selection with SJ733, like cipargamin, has generated point mutations, some unique to SJ733 and not induced by cipargamin, in the pfatp 4 gene $^{28,29}$. The antimalarial properties of PfATP4 inhibitors, such as cipargamin and SJ733, are exceptionally promising and support future development of compounds with this mechanism of action

\section{KAF156}

A novel class of antimalarials, imidazolopiperazines, has recently emerged and been found to have potent asexual bloodstage and liver-stage activity ${ }^{55,56}$. One such imidazolopiperazine, KAF156, is currently in the patient-exploratory stage of the MMV portfolio in combination with lumefantrine. Lumefantrine is a clinically approved partner agent; however, it has been modified to a new once-daily formulation for use with KAF156. In addition to displaying asexual blood- and liver-stage activity, KAF156 also inhibits the growth of sexual bloodstage parasites, including mature gametocytes ${ }^{57}$. Therefore, KAF156 may be effective in preventing parasite transmission from humans to mosquitoes. The antimalarial mechanism of KAF156 is still unclear because resistance in vitro is thought to be indirectly mediated through mutation of pfcarl, pfact, and pfugt, which encode a conserved protein of unknown function, an acetyl-CoA transporter, and a UDP-galactose transporter, respectively ${ }^{25,26,55}$. Future studies may illuminate the parasiticidal mechanism of imidazolopiperazines, but this class of drugs has great potential in the treatment of acute disease and reduction of parasite transmission.

\section{MMV048}

Another novel chemical class of antimalarials, 2-aminopyridines, was identified to have potent single-dose activity against in vitro $P$. falciparum and in vivo $P$. berghe ${ }^{58}$. From this initial screen of 2-aminopyridines, compound 15 (now known as MMV048) was identified with robust antimalarial activity. A follow-up study with MMV048 replicated the potent in vitro and in vivo activity of asexual blood-stage malaria parasites and 
also confirmed transmission-blocking and liver-stage activity ${ }^{27}$. Genomic and chemoproteomic approaches identified Plasmodium phosphatidylinositol 4-kinase (PI4K) as the likely target of MMV048 ${ }^{27}$. PI4K functions in membrane trafficking and membrane assembly during asexual blood-stages ${ }^{59}$. PfPI4K is likely essential during the asexual blood-stage because attempts to insert an early stop codon were unsuccessful ${ }^{59}$. The multi-stage antimalarial activity, prolonged half-life, and singledose efficacy of MMV048 make it a promising new antimalarial in the patient-exploratory stage of the MMV pipeline.

\section{Tafenoquine}

Although infection with $P$. falciparum represents the largest burden of malaria deaths, there is also a need to develop medicines that prevent the relapse of $P$. vivax and $P$. ovale. Unlike $P$. falciparum, both $P$. vivax and $P$. ovale have a dormant liverstage form called a hypnozoite. Hypnozoites can reactivate without warning, leading to the onset of malarial symptoms. This dormant stage remains both a challenge to treat and a potent barrier to malaria elimination. Tafenoquine, an 8-aminoquinoline, is currently under development for the prevention of $P$. vivax relapse. Tafenoquine has high activity as a single-dose treatment and has promising anti-hypnozoite activity in humans ${ }^{60}$. However, tafenoquine has therapeutic restrictions similar to those of the current radical cure standard for $P$. vivax and $P$. ovale, primaquine, which might limit its therapeutic impact. Both primaquine and tafenoquine cause dose-dependent acute hemolytic anemia in individuals with glucose-6-phosphate dehydrogenase deficiency ${ }^{61,62}$. Because of its longer half-life, tafenoquine requires a higher glucose-6-phosphate dehydrogenase activity threshold than primaquine; thus, a greater proportion of individuals will be ineligible for tafenoquine treatment and primaquine will still be needed ${ }^{63}$. In July 2018, the US Food and Drug Administration approved tafenoquine under the trade name Krintafel. Tafenoquine is the first new antimalarial in 60 years to prevent relapse of $P$. vivax. However, its limitations highlight the need for development of additional compounds that target relapsing malaria.

\section{Emerging new antimalarial targets}

Continued efforts to dissect the basic biology of the complex malarial organism have yielded new therapeutic targets for the development of antimalarials. The Plasmodium Genetic Modification Project (PlasmoGEM) (http://plasmogem.sanger. ac.uk), a not-for-profit, open-access research resource, has advanced our understanding of Plasmodium by providing vectors for genome-wide manipulation. PlasmoGEM contains over 2,000 plasmids designed to tag or delete genes in P. berghei ${ }^{64}$. Provided without cost, these tools have been used in a recent large-scale knockout screen to identify essential genes. The essentiality of over $50 \%$ of the genome was tested in an in vivo mouse model of $P$. berghei infection ${ }^{65}$. Surprisingly, $44.9 \%$ of genes were found to be essential and an additional 18\% showed reduced parasite blood-stage growth; therefore, $62.9 \%$ of genes are required in $P$. berghei for normal asexual growth ${ }^{65}$. The high percentage of essential genes and low functional redundancy suggest that Plasmodium may have considerably more drug targets than do bacteria, for example ${ }^{65}$. This genetic screen resulted in the identification of essential cellular processes in the parasite. Specific examples of pathways enriched with essential genes include glycosylphosphatidylinositol anchor biosynthesis, the mitochondrial tricarboxylic acid cycle, ubiquinone biosynthesis, and isoprenoid biosynthesis ${ }^{65}$. From this genetic screen, a searchable phenotype database was built (http://plasmogem. sanger.ac.uk/phenotypes).

A large forward genetic screen in $P$. falciparum parasites recently identified more than 2,680 genes that are likely essential for asexual blood-stage growth ${ }^{66}$. When high-throughput piggyBac transposon insertional mutagenesis was used in combination with quantitative insertion site sequencing ${ }^{67,68}$, the mutability and fitness cost of 5,399 genes were evaluated ${ }^{66}$. The AT-richness of the $P$. falciparum genome $(>81 \%)$ is well suited for piggyBac transposon-based mutagenesis because of the high density of the tetranucleotide insertion target sequence TTAA ${ }^{66}$. To quantify gene essentiality, a mutagenesis index score and mutagenesis fitness score were calculated for each locus. Together, these two independent measures were used to classify a gene as likely essential or dispensable, and this methodology may be expanded to identify essential genes for other life-cycle stages $^{66}$. The essential genes and pathways discovered in both the PlasmoGEM P. berghei screen ${ }^{65}$ and piggyBac transposon $P$. falciparum screen ${ }^{66}$ will supplement ongoing studies and likely initiate investigation into novel putative antimalarial targets.

A final strategy to identify possible new antimalarial targets is the resistance screen. Resistance screens challenge the malaria parasite with low levels of an antimalarial compound to hinder development. This can lead to in vitro evolution and selection for resistance mutations that relieve growth suppression. Therefore, resistance screens can be used to discover both mediators of drug resistance and novel antimalarial drug targets ${ }^{22,69}$. Winzeler and colleagues recently performed a large resistance screen with 37 distinct compounds ${ }^{70}$. Whole genome sequencing of 262 compound-resistant parasite lines identified several candidate resistance mutations. Although the screen confirmed previously identified multi-drug resistance mechanisms and illuminated new drug target-inhibitor pairs, only two novel drug-resistance genes-pfabcl3 and pfaat $1^{70}$-were identified. Below, we highlight a few emerging antimalarial targets of particular promise (Figure 1).

\section{PMIX and PMX}

Two recent studies highlighted the importance of plasmepsins IX (PMIX) and X (PMX) for parasite development ${ }^{71,72}$. Plasmepsins comprise a family of 10 aspartic proteases in the $P$. falciparum genome. A number of studies have focused on the digestive vacuole plasmepsins I to IV (PMI to PMIV), including development of chemical inhibitors ${ }^{73-76}$. Subsequent functional genetic studies of PMI-PMIV revealed that they are not essential for parasite survival ${ }^{77}$. PMIX and PMX are expressed in asexual blood-stage parasites ${ }^{78}$. Conditional knockdown of PMIX in P. falciparum revealed that it is essential for red blood cell invasion ${ }^{71,72}$. PMX knockdown similarly interrupted red blood cell invasion but also revealed an additional requirement of PMX in red blood cell egress ${ }^{72}$. A recent study employed a combination of in vitro and in vivo rodent experiments to find that hydroxyl-ethyl-amine-based scaffold compound 49c (referred 
to as $49 \mathrm{c}$ ) inhibits both PMIX and $\mathrm{PMX}^{71} .49 \mathrm{c}$ is an effective inhibitor against $P$. falciparum in vitro and the rodent parasite Plasmodium berghei in vivo ${ }^{79,80}$. Treatment with $49 \mathrm{c}$ inhibits asexual, sexual, and liver-stage development, indicating that $49 \mathrm{c}$ or other PMIX or PMX inhibitors may have value to both treat symptomatic malaria and block transmission ${ }^{71}$. Together, these observations provide compelling evidence that PMIX and PMX are promising targets for antimalarial development.

\section{Rab11a}

In the recent $P$. berghei functional genetic screen, one of the cellular pathways most enriched with essential genes is that of isoprenoid biosynthesis ${ }^{65}$. A number of studies have previously highlighted the requirement of isoprenoid biosynthesis for $P$. falciparum asexual replication ${ }^{81-83}$. Isoprenoids are necessary for protein prenylation, the post-translational lipid modification of proteins. Because chemical inhibition of protein prenylation in the malaria parasite disrupts asexual parasite growth ${ }^{84-90}$, prenylated malarial proteins are potential antimalarial targets.
Recent chemical labeling approaches have revealed that only 15 to 19 proteins are prenylated in blood-stage malaria and a majority of these proteins are Rab GTPases ${ }^{91,92}$. Rab GTPases function in docking vesicles to membranes and their prenylation aids in association with target membranes ${ }^{93}$. Rab11a, a Rab GTPase, is expressed and prenylated in asexual bloodstage malaria parasites ${ }^{91,92,94}$ and is essential for asexual parasite replication ${ }^{95}$. In the parasite, Rab11a functions as a mediator of PI4K signaling and is a binding partner of PI4K, the target of imidazopyrazines and MMV048 $27,59,96$. Mutation of Rab11a confers resistance to the imidazopyrazine, KAI71559. Interestingly, Rab11a has very low genetic diversity when sequenced in 2,000 Plasmodium clinical isolates, and only one nonsynonymous mutation has been identified ${ }^{97}$. These features suggest that Rab11a may represent a promising target because of both its prenylation and interactions with essential signaling pathways within the parasite. Additional studies are needed to evaluate the biological roles of the remaining prenylated proteins in blood-stage malaria.

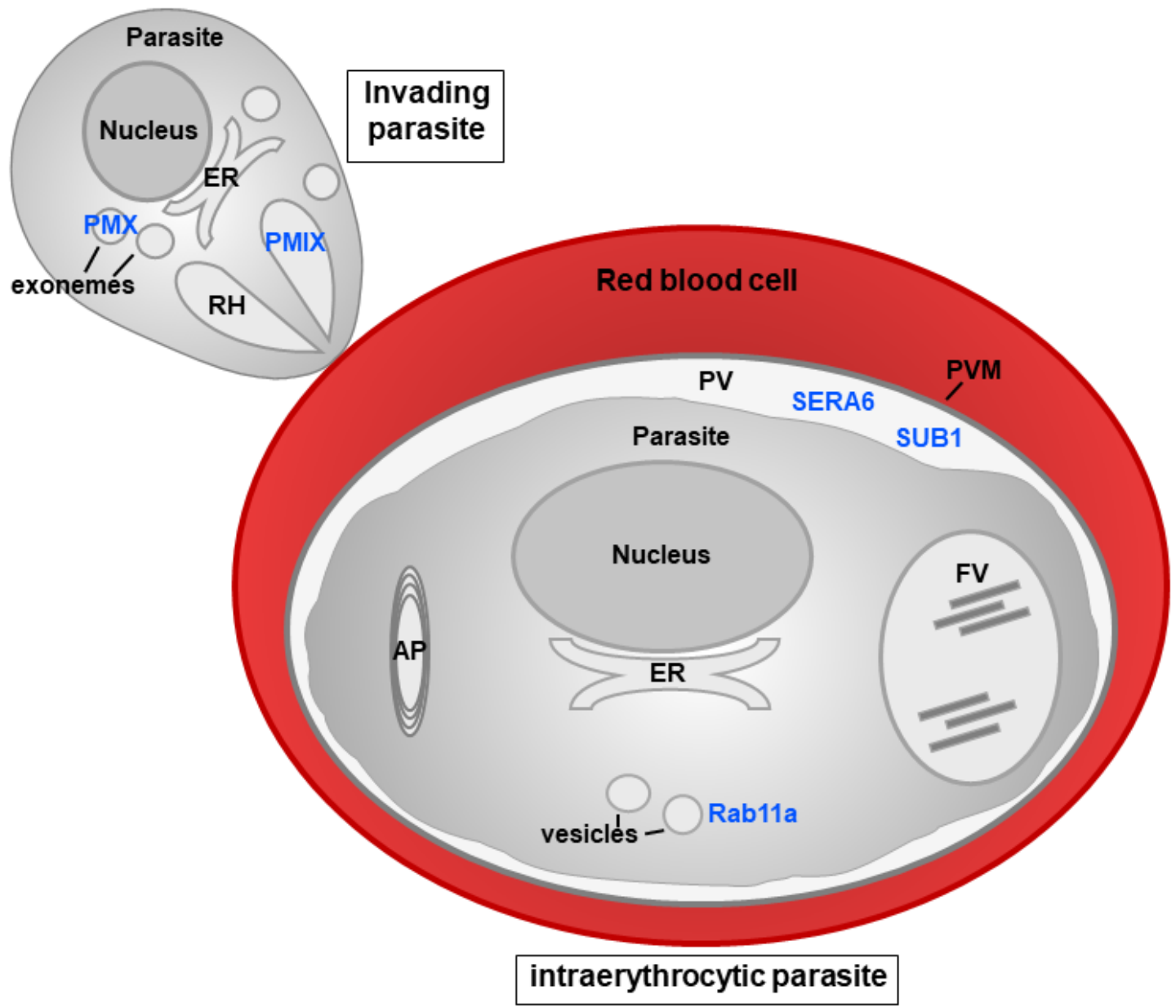

Figure 1. Localization of antimalarial targets in the asexual parasite. Shown are parasite organelles, including the nucleus, apicoplast $(A P)$, endoplasmic reticulum (ER), food vacuole $(F V)$, rhoptries $(R H)$, exonemes, and vesicles. The intraerythrocytic parasite is located within the parasitophorous vacuole (PV), which is delineated by the PV membrane (PVM), where both SUB1 and SERA6 are found during egress ${ }^{98}$. Rab11a likely localizes to vesicles, which it guides to target membranes. In the invading parasite, plasmepsin IX (PMIX) is found in the bulbs of $\mathrm{RH}$ and plasmepsin X (PMX) localizes to exonemes ${ }^{72}$. 


\section{SUB1 and SERA6}

During asexual replication, the malaria parasite must exit the red blood cell before invading a new cell. This process, called egress, requires the rupture of both the parasitophorous vacuole membrane (PVM), which surrounds the parasite, and the red blood cell membrane (RBCM). Egress is protease dependent ${ }^{99}$, and recently two proteases-SUB1 and SERA6-were identified as mediators of PVM and RBCM rupture ${ }^{98}$. SUB1, a serine protease, moves to the parasitophorous vacuole before egress $^{100-104}$ and cleaves multiple substrates ${ }^{100,103,105-107}$. One substrate cleaved by SUB1 is SERA6 ${ }^{108-110}$, a putative cysteine protease, which requires proteolytic processing by SUB1 to function $^{98}$. $P$. falciparum parasites that lack SUB1 fail to rupture the PVM, thus stalling parasite development ${ }^{98}$. Interestingly, parasites that lack SERA6 can rupture the PVM, but RBCM rupture does not occur ${ }^{98}$. Therefore, SUB1 and SERA6 have distinct roles in parasite egress. Because SUB1 and SERA6 are essential for asexual blood-stage growth and orthologues are found in other Plasmodium species ${ }^{98}$, compounds that inhibit these proteins may be useful in treating multiple types of malarial disease.

\section{Discussion}

Malaria continues to be a major global health concern. Plasmodium elimination will not be possible without substantial ongoing efforts, including diagnostic testing and treatment of confirmed and asymptomatic infections, mosquito vector control, preventative therapies, and surveillance systems. Although all of these areas of malaria control are crucial, antimalarial drug discovery is among the most pressing because of the continued spread of antimalarial resistance. The MMV has focused its efforts on developing drugs that treat disease, prevent transmission, and provide chemoprotection. This multifaceted approach to the antimalarial development pipeline provides assurance that new antimalarials will contribute to broad approaches of malaria control.

Studies in basic parasite biology remain extremely important to elimination efforts. Although the current antimalarial compounds under development have great potential, malaria control efforts will benefit from continued dissection of parasite biology. Ideally, new compounds will target proteins and pathways that are essential for parasite growth and transmission with diverse mechanisms of action. New antimalarials will almost certainly be employed in combination therapeutics, combining molecules of different chemical classes and with diverse mechanisms of action to slow the development of multidrug resistance. Novel drug targets will be uncovered through multiple approaches, such as large-scale genetic and resistance screens. A deeper understanding of essential parasite biology will also aid in other aspects of malaria control, including mosquito vector control, advancement of diagnostic tests, and development of preventative therapies. To date, Plasmodium has successfully adapted to sequential drug selective pressure in the field. However, the remarkable successes of recent efforts to develop new antimalarials and identify drug targets suggest an optimistic future in treatment of disease, prevention of transmission, and protection against infection.

\section{Abbreviations}

49c, hydroxyl-ethyl-amine-based scaffold compound 49c; DHODH, dihydroorotate dehydrogenase; MMV, Medicines for Malaria Venture; PI4K, phosphatidylinositol 4-kinase; PlasmoGEM, Plasmodium Genetic Modification Project; PMI, plasmepsin I; PMIV, plasmepsin IV; PMIX, plasmepsin IX; PMX, plasmepsin X; PVM, parasitophorous vacuole membrane; $\mathrm{RBCM}$, red blood cell membrane

\section{Competing interests}

The authors declare that they have no competing interests.

\section{Grant information}

This work was supported by the National Institutes of Health (R01AI103280 and R21AI123808-01 to Audrey Odom John and T32AI007172-37 to Emily Mathews), the Children's Discovery Institute of Washington University and St. Louis Children's Hospital (Audrey Odom John), and the Burroughs Wellcome Fund (to Audrey Odom John).

The funders had no role in study design, data collection and analysis, decision to publish, or preparation of the manuscript.
1. Laveran A: Un nouveau parasite trouvé dans le sang de malades atteints de fièvre palustre. Origine parasitaire des accidents de l'impaludisme. Bull Mém Soc Méd Hôpitaux Paris. 1881; 17: 158-164. Reference Source

2. Manson P: SURGEON-MAJOR RONALD ROSS'S RECENT INVESTIGATIONS on the MOSQUITO-MALARIA THEORY Br Med J 1898; 1(1995): 1575-7. PubMed Abstract | Publisher Full Text | Free Full Text

3. Ross R: The role of the mosquito in the evolution of the malarial parasite: the recent researches of Surgeon-Major Ronald Ross, I.M.S. 1898. Yale J Biol Med. 2002; 75(2): 103-5.

PubMed Abstract | Free Full Text

4. Golgi C: Sul' infezione malarica. Arch Sci Med Torino. 1886; 10: 109-135.

5. Golgi C: Sul ciclo evolutivo dei parassiti malarici nella febbre terzana: diagnosi differenziale tra i parassiti endoglobulari malarici della terzana e quelli della quartana. Arch Sci Med Torino. 1889; 13: 173-196.

6. Grassi B, Bignami A, Bastianelli G: Ulteriore ricerche sul ciclo dei parassiti malarici umani sul corpo del zanzarone. Atti R Accad Lincei. 1899; 8(21-28).

7. World Health Organization: World Malaria Report 2017. Geneva; licence: CC BYNC-SA 3.0 IGO. 2017.

Reference Source

8. Coatney GR: Pitfalls in a Discovery: The Chronicle of Chloroquine. Am J Trop Med Hyg. 1963; 12: 121-8.

PubMed Abstract | Publisher Full Text

9. Ridley RG: Medical need, scientific opportunity and the drive for antimalarial drugs. Nature. 2002; 415(6872): 686-93.

PubMed Abstract | Publisher Full Text 
10. Baird JK: Effectiveness of antimalarial drugs. N Engl J Med. 2005; 352(15): 1565-77.

PubMed Abstract | Publisher Full Text

11. Huang F, Takala-Harrison S, Jacob CG, et al:: A Single Mutation in K13 Predominates in Southern China and Is Associated With Delayed Clearance of Plasmodium falciparum Following Artemisinin Treatment. J Infect Dis. 2015 212(10): 1629-35.

PubMed Abstract | Publisher Full Text | Free Full Text

12. Amaratunga $C$, Sreng S, Suon S, et al:: Artemisinin-resistant Plasmodium falciparum in Pursat province, western Cambodia: a parasite clearance rate study. Lancet Infect Dis. 2012; 12(11): 851-8.

PubMed Abstract | Publisher Full Text | Free Full Text

13. F Phyo AP, Nkhoma S, Stepniewska K, et al.: Emergence of artemisininresistant malaria on the western border of Thailand: a longitudinal study. Lancet. 2012; 379(9830): 1960-6.

PubMed Abstract | Publisher Full Text | Free Full Text | F1000 Recommendation

14. F Dondorp AM, Nosten F, Yi P, et al:: Artemisinin resistance in Plasmodium falciparum malaria. N Engl J Med. 2009; 361(5): 455-67.

PubMed Abstract | Publisher Full Text | Free Full Text | F1000 Recommendation

15. Thriemer K, Hong VN, Rosanas-Urgell A, et al.: Delayed parasite clearance after treatment with dihydroartemisinin-piperaquine in Plasmodium falciparum malaria patients in central Vietnam. Antimicrob Agents Chemother. 2014; 58(12): 7049-55.

PubMed Abstract | Publisher Full Text | Free Full Text

16. F MalariaGEN Plasmodium falciparum Community Project: Genomic epidemiology of artemisinin resistant malaria. eLife. 2016; pii: e08714. PubMed Abstract | Publisher Full Text | Free Full Text | F1000 Recommendation

17. Kyaw MP, Nyunt MH, Chit K, et al:: Reduced susceptibility of Plasmodium falciparum to artesunate in southern Myanmar. PLOS One. 2013; 8(3): e57689. PubMed Abstract | Publisher Full Text | Free Full Text

18. Hien TT, Thuy-Nhien NT, Phu NH, et al.: In vivo susceptibility of Plasmodium falciparum to artesunate in Binh Phuoc Province, Vietnam. Malar J. 2012; 11: 355. PubMed Abstract | Publisher Full Text | Free Full Text

19. Leang R, Taylor WR, Bouth DM, et al.: Evidence of Plasmodium falciparum Malaria Multidrug Resistance to Artemisinin and Piperaquine in Western Cambodia: Dihydroartemisinin-Piperaquine Open-Label Multicenter Clinical Assessment. Antimicrob Agents Chemother. 2015; 59(8): 4719-26. PubMed Abstract | Publisher Full Text | Free Full Text

20. Dondorp AM, Fairhurst RM, Slutsker L, et al.: The threat of artemisinin-resistant malaria. N Engl J Med. 2011; 365(12): 1073-5. PubMed Abstract | Publisher Full Text | Free Full Text

21. Noedl $\mathrm{H}, \mathrm{Se} \mathrm{Y}, \mathrm{Schaecher} \mathrm{K}$, et al.: Evidence of artemisinin-resistant malaria in western Cambodia. N Engl J Med. 2008; 359(24): 2619-20. PubMed Abstract | Publisher Full Text

22. F Ariey F, Witkowski B, Amaratunga C, et al.: A molecular marker of artemisininresistant Plasmodium falciparum malaria. Nature. 2014; 505(7481): 50-5. PubMed Abstract | Publisher Full Text | Free Full Text | F1000 Recommendation

23. F Rottmann M, McNamara C, Yeung BK, et al.: Spiroindolones, a potent compound class for the treatment of malaria. Science. 2010; 329(5996): 1175-80. PubMed Abstract | Publisher Full Text | Free Full Text | F1000 Recommendation

24. Coteron JM, Marco M, Esquivias J, et al.: Structure-guided lead optimization of triazolopyrimidine-ring substituents identifies potent Plasmodium falciparum dihydroorotate dehydrogenase inhibitors with clinical candidate potential. J Med Chem. 2011; 54(15): 5540-61.

PubMed Abstract | Publisher Full Text | Free Full Text

25. LaMonte G, Lim MY, Wree M, et al.: Mutations in the Plasmodium falciparum Cyclic Amine Resistance Locus (PfCARL) Confer Multidrug Resistance. mBio. 2016; 7(4): pii: e00696-16.

PubMed Abstract | Publisher Full Text | Free Full Text

26. Lim MY, LaMonte G, Lee MC, et al.: UDP-galactose and acetyl-CoA transporters as Plasmodium multidrug resistance genes. Nat Microbiol. 2016; 1; 16166. PubMed Abstract | Publisher Full Text | Free Full Text

27. Paquet T, Le Manach C, Cabrera DG, et al.: Antimalarial efficacy of MMV390048, an inhibitor of Plasmodium phosphatidylinositol 4-kinase. Sci Transl Med. 2017; 9(387): pii: eaad9735.

PubMed Abstract | Publisher Full Text | Free Full Text

28. Jiménez-Díaz MB, Ebert D, Salinas $Y$, et al:: (+)-SJ733, a clinical candidate for malaria that acts through ATP4 to induce rapid host-mediated clearance of Plasmodium. Proc Natl Acad Sci U S A. 2014; 111(50): E5455-62.

PubMed Abstract | Publisher Full Text | Free Full Text

29. F Vaidya AB, Morrisey JM, Zhang Z, et al:: Pyrazoleamide compounds are potent antimalarials that target $\mathrm{Na}^{+}$homeostasis in intraerythrocytic Plasmodium falciparum. Nat Commun. 2014; 5: 5521.

PubMed Abstract | Publisher Full Text | Free Full Text | F1000 Recommendation

30. F Straimer J, Gnädig NF, Stokes BH, et al:: Plasmodium falciparum K13 Mutations Differentially Impact Ozonide Susceptibility and Parasite Fitness In Vitro. mBio. 2017; 8(2): pii: e00172-17.

PubMed Abstract | Publisher Full Text | Free Full Text | F1000 Recommendation

31. F Siriwardana A, lyengar K, Roepe PD: Endoperoxide Drug Cross-Resistance Patterns for Plasmodium falciparum Exhibiting an Artemisinin Delayed-Clearance
Phenotype. Antimicrob Agents Chemother. 2016; 60(11): 6952-6.

PubMed Abstract | Publisher Full Text | Free Full Text | F1000 Recommendation

32. $\mathrm{F}$ Yang $\mathrm{T}, \mathrm{Xie} \mathrm{SC}$, Cao $\mathrm{P}$, et al.: Comparison of the Exposure Time Dependence of the Activities of Synthetic Ozonide Antimalarials and Dihydroartemisinin against K13 Wild-Type and Mutant Plasmodium falciparum Strains. Antimicrob Agents Chemother. 2016; 60(8): 4501-10.

PubMed Abstract | Publisher Full Text | Free Full Text | F1000 Recommendation

33. $\mathrm{F}$ Baumgärtner $\mathrm{F}$, Jourdan J, Scheurer $\mathrm{C}$, et al:: In vitro activity of anti-malarial ozonides against an artemisinin-resistant isolate. Malar J. 2017; 16(1): 45. PubMed Abstract | Publisher Full Text | Free Full Text | F1000 Recommendation

34. F Charman SA, Arbe-Barnes S, Bathurst IC, et al.: Synthetic ozonide drug candidate $0 Z 439$ offers new hope for a single-dose cure of uncomplicated malaria. Proc Natl Acad Sci U S A. 2011; 108(11): 4400-5.

PubMed Abstract | Publisher Full Text | Free Full Text | F1000 Recommendation

35. Bolscher JM, Koolen KM, van Gemert GJ, et al:: A combination of new screening assays for prioritization of transmission-blocking antimalarials reveals distinct dynamics of marketed and experimental drugs. J Antimicrob Chemother. 2015; 70(5): 1357-66

PubMed Abstract | Publisher Full Tex

36. F McCarthy JS, Baker M, O'Rourke P, et al.: Efficacy of OZ439 (artefenomel) against early Plasmodium falciparum blood-stage malaria infection in healthy volunteers. J Antimicrob Chemother. 2016; 71(9): 2620-7.

PubMed Abstract | Publisher Full Text | Free Full Text | F1000 Recommendation

7. Daher W, Biot C, Fandeur T, et al:: Assessment of Plasmodium falciparum resistance to ferroquine (SSR97193) in field isolates and in W2 strain under pressure. Malar J. 2006; 5: 11.

PubMed Abstract | Publisher Full Text | Free Full Text

38. Henry M, Briolant S, Fontaine $\mathrm{A}$, et al:: In vitro activity of ferroquine is independent of polymorphisms in transport protein genes implicated in quinoline resistance in Plasmodium falciparum. Antimicrob Agents Chemother. 2008; 52(8): 2755-9.

PubMed Abstract | Publisher Full Text | Free Full Text

39. Barends M, Jaidee A, Khaohirun N, et al:: In vitro activity of ferroquine (SSR 97193) against Plasmodium falciparum isolates from the Thai-Burmese border. Malar J. 2007; 6: 81

PubMed Abstract | Publisher Full Text | Free Full Text

40. Held J, Supan C, Salazar CL, et al.: Ferroquine and artesunate in African adults and children with Plasmodium falciparum malaria: A phase 2, multicentre, randomised, double-blind, dose-ranging, non-inferiority study. Lancet Infect Dis. 2015; 15(12): 1409-19.

PubMed Abstract | Publisher Full Text

41. Wells TN, Hooft van Huijsduijnen R: Ferroquine: Welcome to the next generation of antimalarials. Lancet Infect Dis. 2015; 15: 1365-6.

PubMed Abstract | Publisher Full Text

42. F McCarthy JS, Rückle T, Djeriou E, et al.: A Phase Il pilot trial to evaluate safety and efficacy of ferroquine against early Plasmodium falciparum in an induced blood-stage malaria infection study. Malar J. 2016; 15(1): 469. PubMed Abstract | Publisher Full Text | Free Full Text | F1000 Recommendation

43. Patel V, Booker M, Kramer M, et al.: Identification and characterization of small molecule inhibitors of Plasmodium falciparum dihydroorotate dehydrogenase. J Biol Chem. 2008; 283: 35078-85.

PubMed Abstract | Publisher Full Text | Free Full Text

44. Baldwin J, Michnoff $\mathrm{CH}$, Malmquist NA, et al:: High-throughput screening for potent and selective inhibitors of Plasmodium falciparum dihydroorotate dehydrogenase. J Biol Chem. 2005; 280(23): 21847-53.

PubMed Abstract | Publisher Full Text

45. Phillips MA, Lotharius J, Marsh $\mathrm{K}$, et al:: A long-duration dihydroorotate dehydrogenase inhibitor (DSM265) for prevention and treatment of malaria. Sci Transl Med. 2015; 7(296): 296ra111.

PubMed Abstract | Publisher Full Text | Free Full Text

46. F Sulyok M, Rückle T, Roth A, et al.: DSM265 for Plasmodium falciparum chemoprophylaxis: A randomised, double blinded, phase 1 trial with controlled human malaria infection. Lancet Infect Dis. 2017; 17(6): 636-44. PubMed Abstract | Publisher Full Text | Free Full Text | F1000 Recommendation

47. F Murphy SC, Duke ER, Shipman KJ, et al.: A Randomized Trial Evaluating the Prophylactic Activity of DSM265 Against Preerythrocytic Plasmodium falciparum Infection During Controlled Human Malarial Infection by Mosquito Bites and Direct Venous Inoculation. J Infect Dis. 2018; 217(5): 693-702. PubMed Abstract | Publisher Full Text | Free Full Text | F1000 Recommendation

48. Yeung BK, Zou B, Rottmann M, et al.: Spirotetrahydro beta-carbolines (spiroindolones): a new class of potent and orally efficacious compounds for the treatment of malaria. J Med Chem. 2010; 53(14): 5155-64. PubMed Abstract | Publisher Full Text

49. F White NJ, Pukrittayakamee S, Phyo AP, et al:: Spiroindolone KAE609 for falciparum and vivax malaria. N Engl J Med. 2014; 371(5): 403-10. PubMed Abstract | Publisher Full Text | Free Full Text | F1000 Recommendation

50. Kirk K: Ion Regulation in the Malaria Parasite. Annu Rev Microbiol. 2015; 69: 341-59.

PubMed Abstract | Publisher Full Text

51. Spillman $\mathrm{NJ}$, Allen $\mathrm{RJ}, \mathrm{McNamara} \mathrm{CW}$, et al.: $\mathrm{Na}^{+}$regulation in the malaria 
parasite Plasmodium falciparum involves the cation ATPase PfATP4 and is a target of the spiroindolone antimalarials. Cell Host Microbe. 2013; 13(2): 227-37. PubMed Abstract | Publisher Full Text | Free Full Text

52. van Pelt-Koops JC, Pett HE, Graumans W, et al.: The spiroindolone drug candidate NITD609 potently inhibits gametocytogenesis and blocks Plasmodium falciparum transmission to anopheles mosquito vector. Antimicrob Agents Chemother. 2012; 56(7): 3544-8

PubMed Abstract | Publisher Full Text | Free Full Text

53. Flannery EL, McNamara CW, Kim SW, et al:: Mutations in the P-type cationtransporter ATPase 4, PfATP4, mediate resistance to both aminopyrazole and spiroindolone antimalarials. ACS Chem Biol. 2015; 10(2): 413-20. PubMed Abstract | Publisher Full Text | Free Full Text

54. Lehane AM, Ridgway MC, Baker E, et al:: Diverse chemotypes disrupt ion homeostasis in the Malaria parasite. Mol Microbiol. 2014; 94(2): 327-39. PubMed Abstract | Publisher Full Tex

55. F Meister S, Plouffe DM, Kuhen KL, et al:: Imaging of Plasmodium liver stages to drive next-generation antimalarial drug discovery. Science. 2011; 334(6061): $1372-7$.

PubMed Abstract | Publisher Full Text | Free Full Text | F1000 Recommendation

56. Wu T, Nagle A, Kuhen K, et al:: Imidazolopiperazines: hit to lead optimization of new antimalarial agents. J Med Chem. 2011; 54(14): 5116-30. PubMed Abstract | Publisher Full Text

57. Kuhen KL, Chatterjee AK, Rottmann M, et al:: KAF156 is an antimalarial clinical candidate with potential for use in prophylaxis, treatment, and prevention of disease transmission. Antimicrob Agents Chemother. 2014; 58(9): 5060-7. PubMed Abstract | Publisher Full Text | Free Full Text

58. Younis $Y$, Douelle F, Feng TS, et al: 3,5-Diaryl-2-aminopyridines as a nove class of orally active antimalarials demonstrating single dose cure in mice and clinical candidate potential. J Med Chem. 2012; 55(7): 3479-87. PubMed Abstract | Publisher Full Tex

59. F McNamara CW, Lee MC, Lim CS, et al:: Targeting Plasmodium PI(4)K to eliminate malaria. Nature. 2013; 504(7479): 248-53.

PubMed Abstract | Publisher Full Text | Free Full Text | F1000 Recommendation

60. F Beck HP, Wampfler R, Carter N, et al.: Estimation of the Antirelapse Efficacy of Tafenoquine, Using Plasmodium vivax Genotyping. J Infect Dis. 2016; 213(5): 794-9.

PubMed Abstract | Publisher Full Text | Free Full Text | F1000 Recommendation

61. F Rueangweerayut R, Bancone G, Harrell EJ, et al:: Hemolytic Potential of Tafenoquine in Female Volunteers Heterozygous for Glucose-6-Phosphate Dehydrogenase (G6PD) Deficiency (G6PD Mahidol Variant) versus G6PDNormal Volunteers. Am J Trop Med Hyg. 2017; 97(3): 702-11.

PubMed Abstract | Publisher Full Text | Free Full Text | F1000 Recommendation

62. ALVING AS, JOHNSON CF, TARLOV AR, et al:: Mitigation of the haemolytic effect of primaquine and enhancement of its action against exoerythrocytic forms of the Chesson strain of Piasmodium vivax by intermittent regimens of drug administration: a preliminary report. Bull World Health Organ. 1960; 22 $621-31$

PubMed Abstract | Free Full Text

63. F Watson J, Taylor WRJ, Bancone G, et al:: Implications of current therapeutic restrictions for primaquine and tafenoquine in the radical cure of vivax malaria. PLoS Negl Trop Dis. 2018; 12(4): e0006440.

PubMed Abstract | Publisher Full Text | Free Full Text | F1000 Recommendation

64. Schwach F, Bushell E, Gomes AR, et al:: PlasmoGEM, a database supporting a community resource for large-scale experimental genetics in malaria parasites. Nucleic Acids Res. 2015; 43(Database issue): D1176-82. PubMed Abstract | Publisher Full Text | Free Full Text

65. F Bushell E, Gomes AR, Sanderson T, et al:: Functional Profiling of a Plasmodium Genome Reveals an Abundance of Essential Genes. Cell. 2017; 170(2): 260-272.e8

PubMed Abstract | Publisher Full Text | Free Full Text | F1000 Recommendation

66. F Zhang M, Wang C, Otto TD, et al:: Uncovering the essential genes of the human malaria parasite Plasmodium falciparum by saturation mutagenesis. Science. 2018; 360(6388): pii: eaap7847.

PubMed Abstract | Publisher Full Text | F1000 Recommendation

67. Bronner IF, Otto TD, Zhang M, et al:: Quantitative insertion-site sequencing (QIseq) for high throughput phenotyping of transposon mutants. Genome Res. 2016; 26(7): 980-9.

PubMed Abstract | Publisher Full Text | Free Full Text

68. F Hart T, Chandrashekhar M, Aregger M, et al:: High-Resolution CRISPR Screens Reveal Fitness Genes and Genotype-Specific Cancer Liabilities. Cell. 2015; 163(6): 1515-26.

PubMed Abstract | Publisher Full Text | F1000 Recommendation

69. Flannery EL, Fidock DA, Winzeler EA: Using genetic methods to define the targets of compounds with antimalarial activity. J Med Chem. 2013; 56(20): 7761-71.

PubMed Abstract | Publisher Full Text | Free Full Text

70. F Cowell AN, Istvan ES, Lukens AK, et al:: Mapping the malaria parasite druggable genome by using in vitro evolution and chemogenomics. Science. 2018; 359(6372): 191-9.

PubMed Abstract | Publisher Full Text | Free Full Text | F1000 Recommendation
71. F Pino $\mathrm{P}$, Caldelari $\mathrm{R}$, Mukherjee $\mathrm{B}$, et al: A multistage antimalarial targets the plasmepsins IX and $X$ essential for invasion and egress. Science. 2017; 358(6362): 522-8

PubMed Abstract | Publisher Full Text | Free Full Text | F1000 Recommendation

72. $\mathbf{F}$ Nasamu AS, Glushakova S, Russo I, et al:: Plasmepsins IX and $\mathbf{X}$ are essential and druggable mediators of malaria parasite egress and invasion. Science. 2017; 358(6362): 518-22.

PubMed Abstract | Publisher Full Text | Free Full Text | F1000 Recommendation

3. Bhaumik $P$, Gustchina A, Wlodawer A: Structural studies of vacuolar plasmepsins. Biochim Biophys Acta. 2012; 1824(1): 207-23.

PubMed Abstract | Publisher Full Text | Free Full Text

74. Meyers MJ, Goldberg DE: Recent advances in plasmepsin medicinal chemistry and implications for future antimalarial drug discovery efforts. CTMC. 2012; 12(5): 445-55.

PubMed Abstract | Publisher Full Text

75. Boss C, Richard-Bildstein S, Weller T, et al: Inhibitors of the Plasmodium falciparum parasite aspartic protease plasmepsin II as potential antimalarial agents. CMC. 2003; 10(11): 883-907.

PubMed Abstract | Publisher Full Text

76. Rasina D, Otikovs M, Leitans J, et al.: Fragment-Based Discovery of 2 Aminoquinazolin-4(3H)-ones As Novel Class Nonpeptidomimetic Inhibitors of the Plasmepsins I, II, and IV. J Med Chem. 2016; 59(1): 374-87. PubMed Abstract | Publisher Full Text

77. Bonilla JA, Bonilla TD, Yowell CA, et al:: Critical roles for the digestive vacuole plasmepsins of Plasmodium falciparum in vacuolar function. Mol Microbiol. 2007; 65(1): 64-75.

PubMed Abstract | Publisher Full Text

78. Banerjee R, Liu J, Beatty W, et al.: Four plasmepsins are active in the Plasmodium falciparum food vacuole, including a protease with an active-site histidine. Proc Natl Acad Sci U S A. 2002; 99(2): 990-5. PubMed Abstract | Publisher Full Text | Free Full Text

79. Ciana $\mathrm{C}$, Siegrist $\mathrm{R}$, Aissaoui $\mathrm{H}$, et al.: Novel in vivo active anti-malarials based on a hydroxy-ethyl-amine scaffold. Bioorg Med Chem Lett. 2013; 23(3): 658-62. PubMed Abstract | Publisher Full Text

80. F Guiguemde WA, Shelat AA, Bouck D, et al:: Chemical genetics of Plasmodium falciparum. Nature. 2010; 465(7296): 311-5. PubMed Abstract | Publisher Full Text | Free Full Text | F1000 Recommendation

81. Zhang B, Watts KM, Hodge D, et al:: A second target of the antimalarial and antibacterial agent fosmidomycin revealed by cellular metabolic profiling. Biochemistry. 2011: 50(17): 3570-7.

PubMed Abstract | Publisher Full Text | Free Full Text

82. F Yeh E, DeRisi JL: Chemical rescue of malaria parasites lacking an apicoplast defines organelle function in blood-stage Plasmodium falciparum PLOS Biol. 2011; 9(8): e1001138.

PubMed Abstract | Publisher Full Text | Free Full Text | F1000 Recommendation

83. Jomaa H, Wiesner J, Sanderbrand S, et al:: Inhibitors of the Nonmevalonate Pathway of Isoprenoid Biosynthesis as Antimalarial Drugs. Science. 1999; 285(5433): 1573-6.

PubMed Abstract | Publisher Full Tex

84. Buckner FS, Eastman RT, Yokoyama K, et al:: Protein farnesyl transferase inhibitors for the treatment of malaria and African trypanosomiasis. Curr Opin Investig Drugs. 2005; 6(8): 791-7.

PubMed Abstract

85. Glenn MP, Chang SY, Hucke O, et al.: Structurally simple farnesyltransferase inhibitors arrest the growth of malaria parasites. Angew Chem Int Ed Engl. 2005; 44(31): 4903-6.

PubMed Abstract | Publisher Full Text

86. Glenn MP, Chang SY, Hornéy C, et al.: Structurally simple, potent, Plasmodium selective farnesyltransferase inhibitors that arrest the growth of malaria parasites. J Med Chem. 2006; 49(19): 5710-27. PubMed Abstract | Publisher Full Text | Free Full Text

87. Nallan L, Bauer KD, Bendale $P$, et al.: Protein farnesyltransferase inhibitors exhibit potent antimalarial activity. J Med Chem. 2005; 48(11):3704-13. PubMed Abstract | Publisher Full Text

88. Howe R, Kelly M, Jimah J, et al:: Isoprenoid biosynthesis inhibition disrupts Rab5 localization and food vacuolar integrity in Plasmodium falciparum. Eukaryot Cell. 2013; 12(2): 215-23. PubMed Abstract | Publisher Full Text | Free Full Text

89. Chakrabarti D, Da Silva T, Barger J, et al.: Protein farnesyltransferase and protein prenylation in Plasmodium falciparum. J Biol Chem. 2002; 277(44) 42066-73.

PubMed Abstract | Publisher Full Tex

90. Chakrabarti D, Azam T, DelVecchio C, et al.: Protein prenyl transferase activities of Plasmodium falciparum. Mol Biochem Parasitol. 1998; 94(2): 175-84. PubMed Abstract | Publisher Full Text

91. Gisselberg JE, Zhang L, Elias JE, et al.: The Prenylated Proteome of Plasmodium falciparum Reveals Pathogen-specific Prenylation Activity and Drug Mechanism-of-action. Mol Cell Proteomics. 2017; 16(4 suppl 1): S54-S64. PubMed Abstract | Publisher Full Text | Free Full Text

92. Suazo KF, Schaber C, Palsuledesai CC, et al.: Global proteomic analysis of prenylated proteins in Plasmodium falciparum using an alkyne-modified 
isoprenoid analogue. Sci Rep. 2016; 6: 38615

PubMed Abstract | Publisher Full Text | Free Full Text

93. Gomes AQ, Ali BR, Ramalho JS, et al.: Membrane targeting of Rab GTPases is influenced by the prenylation motif. Mol Biol Cell. 2003; 14(5): 1882-99. PubMed Abstract | Publisher Full Text | Free Full Text

94. Quevillon E, Spielmann T, Brahimi K, et al:: The Plasmodium falciparum family of Rab GTPases. Gene. 2003; 306: 13-25. PubMed Abstract | Publisher Full Tex

95. Agop-Nersesian C, Naissant B, Ben Rached F, et al:: Rab11A-controlled assembly of the inner membrane complex is required for completion of apicomplexan cytokinesis. PLoS Pathog. 2009; 5(1): e1000270. PubMed Abstract | Publisher Full Text | Free Full Text

96. F Burke JE, Inglis AJ, Perisic O, et al.: Structures of PI4KIII 3 complexes show simultaneous recruitment of Rab11 and its effectors. Science. 2014; 344(6187): 1035-8.

PubMed Abstract | Publisher Full Text | Free Full Text | F1000 Recommendation

97. F Gomes AR, Ravenhall M, Benavente ED, et al.: Genetic diversity of next generation antimalarial targets: $A$ baseline for drug resistance surveillance programmes. Int J Parasitol Drugs Drug Resist. 2017; 7(2): 174-80. PubMed Abstract | Publisher Full Text | Free Full Text | F1000 Recommendation

98. F Thomas JA, Tan MSY, Bisson C, et al:: A protease cascade regulates release of the human malaria parasite Plasmodium falciparum from host red blood cells. Nat Microbiol. 2018; 3(4): 447-55.

PubMed Abstract | Publisher Full Text | F1000 Recommendation

99. Blackman MJ: Malarial proteases and host cell egress: an 'emerging' cascade. Cell Microbiol. 2008; 10(10): 1925-34 PubMed Abstract | Publisher Full Text | Free Full Text

100. F Yeoh S, O'Donnell RA, Koussis K, et al.: Subcellular discharge of a serine protease mediates release of invasive malaria parasites from host erythrocytes. Cell. 2007; 131(6): 1072-83. PubMed Abstract | Publisher Full Text | F1000 Recommendation

101. Collins $\mathrm{CR}$, Hackett $\mathrm{F}$, Strath M, et al:: Malaria parasite cGMP-dependent protein kinase regulates blood stage merozoite secretory organelle discharge and egress. PLoS Pathog. 2013; 9(5): e1003344. PubMed Abstract | Publisher Full Text | Free Full Text

102. Withers-Martinez $C$, Strath M, Hackett $F$, et al:: The malaria parasite egress protease SUB1 is a calcium-dependent redox switch subtilisin. Nat Commun. 2014; 5: 3726

PubMed Abstract | Publisher Full Text | Free Full Text

103. Das S, Hertrich N, Perrin AJ, et al.: Processing of Plasmodium falciparum Merozoite Surface Protein MSP1 Activates a Spectrin-Binding Function Enabling Parasite Egress from RBCs. Cell Host Microbe. 2015; 18(4): 433-44. PubMed Abstract | Publisher Full Text | Free Full Text

104. F Hale VL, Watermeyer JM, Hackett F, et al:: Parasitophorous vacuole poration precedes its rupture and rapid host erythrocyte cytoskeleton collapse in Plasmodium falciparum egress. Proc Natl Acad Sci U S A. 2017; 114(13): 3439-44.

114(13): 3439-44.
PubMed Abstract | Publisher Full Text | Free Full Text | F1000 Recommendation

105. Koussis K, Withers-Martinez C, Yeoh S, et al: A multifunctional serine protease primes the malaria parasite for red blood cell invasion. EMBO J. 2009; 28(6): 725-35.

PubMed Abstract | Publisher Full Text | Free Full Text

106. Silmon de Monerri NC, Flynn HR, Campos MG, et al:: Global identification of multiple substrates for Plasmodium falciparum SUB1, an essential malarial processing protease. Infect Immun. 2011; 79(3): 1086-97. PubMed Abstract | Publisher Full Text | Free Full Text

107. $\mathrm{F}$ Collins $\mathrm{CR}$, Hackett $\mathrm{F}$, Atid J, et al:: The Plasmodium falciparum pseudoprotease SERA5 regulates the kinetics and efficiency of malaria parasite egress from host erythrocytes. PLoS Pathog. 2017; 13(7): e1006453. PubMed Abstract | Publisher Full Text | Free Full Text | F1000 Recommendation

108. Ruecker A, Shea M, Hackett F, et al:: Proteolytic activation of the essential parasitophorous vacuole cysteine protease SERA6 accompanies malaria parasite egress from its host erythrocyte. J Biol Chem. 2012; 287(45): 37949-63. PubMed Abstract | Publisher Full Text | Free Full Text

109. F Miller SK, Good RT, Drew DR, et al:: A subset of Plasmodium falciparum SERA genes are expressed and appear to play an important role in the erythrocytic cycle. J Biol Chem. 2002; 277(49): 47524-32. PubMed Abstract | Publisher Full Text | F1000 Recommendation

110. Thomas JA, Collins CR, Das S, et al.: Development and Application of a Simple Plaque Assay for the Human Malaria Parasite Plasmodium falciparum. PLOS One. 2016; 11(6): e0157873.

PubMed Abstract | Publisher Full Text | Free Full Text 


\section{Open Peer Review}

\section{Current Peer Review Status:}

\section{Editorial Note on the Review Process}

Faculty Reviews are review articles written by the prestigious Members of Faculty Opinions. The articles are commissioned and peer reviewed before publication to ensure that the final, published version is comprehensive and accessible. The reviewers who approved the final version are listed with their names and affiliations.

\section{The reviewers who approved this article are:}

\section{Version 1}

\section{Emily Derbyshire}

Department of Molecular Genetics and Microbiology, Duke University Medical Center, Durham, North Carolina, USA

Competing Interests: No competing interests were disclosed.

\section{Kirsten Hanson}

Department of Biology and the South Texas Center for Emerging Infectious Diseases, University of Texas at San Antonio, San Antonio, Texas, USA

Competing Interests: No competing interests were disclosed.

The benefits of publishing with F1000Research:

- Your article is published within days, with no editorial bias

- You can publish traditional articles, null/negative results, case reports, data notes and more

- The peer review process is transparent and collaborative

- Your article is indexed in PubMed after passing peer review

- Dedicated customer support at every stage

For pre-submission enquiries, contact research@f1000.com 